\title{
CINEMA AND ARCHITECTURE: MODERN PERCEPTION
}

\section{A B S T R A C T}

Walter Benjamin's essay on cinema expounds his prognostic values. By the time he wrote this article his critique of the capitalistic mode of production showed the direction in which capitalism was progressing: towards an increasing intensity in exploitation of the proletariat, but also its own decline. We are interested in these prognoses that affirm the transformation of art and its function, and which call our attention to the loss of transcendence and the decline of the aura of the work of art. At the same time, they show possibilities that affirm the continuity of art with a different role and the dislocation of the aura. The form of art that is suitable to this reflection is cinema and the parallel drawn by the philosopher between cinema and architecture. Our intention is to reflect on this parallel and the urban interventions as artistic forms of aesthetic modernity: that is, as products of this modernity that at the same time indicate the way the world is given to us and understood by us. We will also reflection cinema and theatre indications as a way to surpass corporal determinations that are imposed on us. 


\section{CINEMA AND ARCHITECTURE: MODERN PERCEPTION}

In his essay on artwork, Walter Benjamin compares Karl Marx's prognostics derived from his analysis of commodity in the Capital with his own prognostics based on his analysis of art. Marx presented his analysis in a way which showed what could be expected of capitalism in the future ${ }^{1}$. At that time his critique of the capitalistic mode of production showed the direction in which capitalism was progressing: towards an increasing intensity in the exploitation of the proletariat, but also its own abolition.

For Benjamin, the moment in which he writes the essay is suitable for a new prognosis. Unlike Marx's analysis, whose prognoses have taken half a century to be observed, Benjamin's are referred to as the "tendencies of development of art" $^{\prime 2}$ which can be immediately observed.

Our focus are the prognostics that affirm the transformation of art and its function, and call our attention to the loss of transcendence and the decline of aura in the work of art. At the same time they show possibilities that affirm the continuity of art with a different role and the dislocation of the aura.

Every form of mature art is at a point of intersection of three developmental lines ${ }^{3}$ : 1) the action of technique on the form of art; 2) the realisation by the new form of art of the effects that traditional forms of art tried to produce in the past; 3) the utilisation by the new forms of art of the changes in the structure of perception. ${ }^{4}$

For Benjamin the reception of contemporary art occurs in a scattered and collective way. This is due to the profound changes in human perception, an indispensable condition when we think about contemporary art. Cinema and architecture are the two forms of art whose reception is distinguished by these two traits because cinematographic and architectural works conform to the format of an art produced to be received by the masses, which has a "new attitude toward the work of art". ${ }^{5}$ This form of distracted reception was first discredited when compared to that of the specialist. ${ }^{6}$ This form of perception is related to how the mass appropriates the work of art so as to bring it close. The oldest and clearest example of this form of reception is architecture. 'Architecture has always offered the prototype of an artwork that is received in a state of distraction and through the collective. ${ }^{7}$

Architecture is a form of art that finds its sense in this mode of reception. There is a paradox in this mode of reception of art because the sense of its existence is a collective reception: it is involved by the masses but it also gives form to 
the mass reception. This change of emphasis in the mode of reception interferes in the mode of contemplation. If, previously, the optical reception related to this last mode, it is now determined ${ }^{8}$ by habit, or tactile mode of reception. For Benjamin, the reason why this happens is that: 'The tasks which face the human apparatus of perception at historical turning points cannot be performed solely by optical means, that is, by way of contemplation'. ${ }^{9}$ We will never develop the habits we need to survive in the modern city through contemplation or mental activity. The body apprehends these tasks more quickly, just as Baudelaire's Apache learns how to situate himself in the big city as if it were a forest.

First consequence: This new form of reception of art realises a task that is necessary to humanity. Architecture has an important role because this form of art is essential in understanding the relationship of the masses to art. ${ }^{10}$ Second consequence: the form of reception of art by the masses is imposed on the individual even if the individual tries to avoid the task. The individual's resistance is overcome by the strength of the masses, which does not necessarily follow the right direction owing to this resistance. There is a task to be fulfilled; there is a strength that pushes it to its realisation. The result will depend on the consideration of this demand. If it is not considered, this movement will follow the direction imposed by the nature of strength. 'Art will tackle the most difficult and most important tasks wherever it is able to mobilise the masses. It does so currently in film'. ${ }^{11}$

Architecture can help us understand what Benjamin means. To understand architecture nowadays it is necessary to believe in it as we believe in other arts. We must observe its injunctions and discover how it is applied. In architecture, tactility and habit of tactile reception have primacy over visual mode of reception and contemplation in a more radical way, as in sculpture. We need another kind of aesthetic act. ${ }^{12}$ The habitual viewer who looks is less attentive, as if the existence of architecture was evident and did not deserve a determined act of attention. He transforms himself into a customer or into someone who strolls. As Benjamin said, the architectural monument is perceived in a state of distraction.

\section{a)}

For Hegels affirmation architecture coincides with the symbolic form of art, ${ }^{13}$ in which the Idea still looks for its authentic artistic expression. It is still abstract and undetermined, it does not have the adequate phenomenon in in itself, is opposed to natural external things and to human facts. ${ }^{14}$ Its objectivity and 
particularity expresses its own abstractions of which it is not aware. When these abstractions are objects of knowledge, architecture will necessarily take another form and have another function, different from that which it had at the moment it emerged, and immediately after. The beginning of architecture occurred when man searched for a place to inhabit - a cave or a tree trunk. This trunk or cave could not be considered as a product of an artistic intention because they did not express an objective per se. ${ }^{15}$ When houses and temples were built we still had the satisfaction of a necessity that was out of art's field, and this 'satisfaction [of a necessity] in conformity to an end has nothing to do with fine art' ${ }^{9}{ }^{16}$ It is not yet art; it can only be art if we add to this conformity to an end the 'impetus for form and artistic beauty'. ${ }^{17}$ This double aspect in architecture, satisfaction of a need and satisfaction of a need with beauty, reveals a division that cannot be in its origin, and that already reveals to Hegel where to look for the "origin of art": in the works that do not bring its meaning through another purpose or need, but through themselves. ${ }^{18}$

Autonomous or inorganic architecture builds configurations that exist for themselves, but they are still attached to a corporeal form which is inadequate for beauty and to the free appearance of the spirit. That is why it cannot remain in this point of departure, but searches to express the exterior nature as a cover (wrap) configured by the spirit through art. This means that the progress of art is to be found in the possibility to emphasise the difference between the means and the ends. The end would already be contained in both moments: in the building of temples and palaces, or individual sculpture. This difference between the means and the ends detected in architecture by Hegel has already been criticised by Benjamin in his essay Critique of Violence, in which he focusses his analysis on questions concerning law and right. For Benjamin the aesthetic act is full of meaning: to build a house is already expression of an idea. Its meaning does not come later. The meaning for Hegel is established afterwards with rational reflection, but for Benjamin it comes together with the action.

If architecture remains the means to accomplish the ends that are alien to it, in his exposition of the history of architecture, Hegel traces in parallel and unconsciously, a history of the forgetfulness of the body and material life. This is what Benjamin looks forward to bringing to the centre of his reflection.

Benjamin replaces the discussion on matter and body when in his essay he treats art as a matter of perception, of aisthesis (like the Greek). Architecture is, in this sense, the art that makes it possible to lead reflection to this point, because it is, since the beginning 'a work of art that is received in a state of distraction' ${ }^{19}$ This 
collective reception is the corporal reception of the mass that walks through the constructions of the big cities. The history of architecture makes it easier to understand the historical relation between the masses and the work of art, or we can say that architecture is the art that makes it possible to bring the relation between the masses and art to the centre of the reflection on modern and contemporaneous art. And this relationship brings to the centre of this reflection not contemplation of art through optical means, but perception through tactile means. It is the rise of a new technique, the film, which puts the reception of art through tactile means at the centre of aesthetic problems. Film cannot be received through contemplation, and cinema appears to respond to a necessity of human apparatus of perception: we need to learn how to perceive with our tactile organs because this perception will lead us out of the labyrinth created by traditional patterns of reflection.

\section{b)}

Film shows that 'tactile dominance prevails in the optical universe itself' ${ }^{20}$ No matter how much modern analysis of society has insisted on the fact that vision prevails over other senses, Benjamin insists that the visual stimulus is dominated by the tactile, which means that visual stimulus follows a programme already established by a habit. Film not only shows that, but also makes possible its abolition. The violent tensions of our time can be perceived because in film the tactile dominant prevails over the optical one; Film offers the possibility to disorganise this prevalence, not to re-establish the optical, but in the name of a better comprehension of the phenomena of perception. If film shows that 'tactile dominance prevails in the optical universe itself, ${ }^{21}$ we can also confirm that if tactile reception is accomplished through a habit, habit determines optical reception. ${ }^{22}$

Optical reception is determined by the way buildings organise the use of space. Benjamin has in mind at this point the utilisation by fascism of the growing massification. ${ }^{23}$ This means to transform political life in images in which the masses appear as playing the leading role but in fact they are images in which the masses play the role of the masses.

The apprehension that optical component is determined by the tactile is an important knowledge in the game of politics, which is efficiently conducted by the Nazis. It is important for Benjamin to take seriously the social function of film: the 'initiation of humanity into this harmonious play [...]between natural forces and mankind ${ }^{24}$ and act so that the masses are offered an opportunity to 
perceive both: 1) the tactile determination over the optical; and 2) the possibilities that optical dominance offers to tactile experimentation. The masses' tactile reception can teach us much about the reception of works of art. Those to which we dedicate concentrated attention are the works of art that we contemplate from acquired habits. ${ }^{25}$

'By its use of close-ups, by its accentuation of hidden details in familiar objects, and by its exploration of commonplace milieux through the ingenious guidance of the camera; on the other hand, it manages to assure us of a vast and unsuspected field of action [Spielraum] ${ }^{,}{ }^{26}$

The explosion of the "prison-world" is possible because man is alienated by the representation of his image. This alienation, however, has a productive use: it produces estrangement; man fails to recognise his own image projected on the screen. We can now examine what we see without knowing. The film exhibits on the screen elements of a collective dream. These images are a kind of elixir for the 'the dangerous tensions which technology and its consequences have engendered in the masses at large-tendencies $;{ }^{9}$ mechanisation itself created that which can make the masses immune to its dangers. Film is a product of the innervations of collective elements that search for the satisfaction of a desire for a better life. These innervations create, at the same time, the technique which immunises the masses against its harmful effects. In Benjamin's view there is a need to laugh at what we create, and that is not catharsis.

For Benjamin these two features of film will be useful to man in order for him to free himself from the demands imposed by a capitalist society: 1) film makes us perceive the restrictions that determine our existence; ${ }^{28} 2$ ) and film assures us of an immense and unexpected field of action. The recording of our actions allows us to realise that they are the result of a detailed and involuntary montage, and to see our world as a constructed scenario. The camera penetrates deep into the web of reality and reveals what takes place in the interstice of this "optical unconscious" thus making us aware of what determines our view, in the same way that unconscious impulses determine our actions. So Benjamin's aisthesis is, at the same time, close to and far from Greek insofar as he affirms that there is something beyond the reach of vision, but it is not invisible, but perceptible.

Unlike architecture in its different moments, film in modernity accounts for the intense existential dangers of modern man and the tensions of our time. Is it still so today? 
Walter Benjamin, Das Kunstwerk im Zeitalter seiner technischen Reproduzierbarkei, (Frankfurt, Suhrkamp Verlag, 1980), 435.(cit. as Kunstwerk). There is certainly a change in the attitude not only of the masses in relation to works of art, but of art itself in relation to its public, made explicit by Benjamin in the concepts of cult value and exhibition value.

Benjamin, Kunstwerk, 435.

Benjamin, Kunstwerk, 456-7.

Benjamin, Kunstwerk, 457.

Benjamin, Kunstwerk, 465.

"The distracted masses absorb the work of art into themselves. Their waves lap around it; they encompass it with their tide, Benjamin, Kunstwerk, 495.

Benjamin, Kunstwerk, 465.

Benjamin, Kunstwerk, 466 .

Benjamin, Kunstwerk, 466.

Benjamin, Kunstwerk, 465.

Benjamin, Kunstwerk, 465.

Goetz, Benoît - La dislocation. Architecture et Philosophie. (Paris, Les éditions de la Passion, 2002).

Hegel, G. W. F. Cursos de Estética, trans. Marco A.Werle/Oliver Tolle (São Paulo: EDUSP, 2000. Volume III) 2002, 35.

Hegel, Cursos de Estética, 20.

Hegel, Cursos de Estética, 34.

Hegel, Cursos de Estética, 35.

Hegel, Cursos de Estética, 35.

Hegel, Cursos de Estética, 35.

Benjamin, Kunstwerk, 465.

Benjamin, Kunstwerk, 466.

Benjamin, Kunstwerk, 465.

Benjamin, Kunstwerk, 466.

"Fascism attempts to organize the newly proletarianized masses", Benjamin, Kunstwerk, 465.

Benjamin, L'oeuvre d'art à l'époque de sa reproduction mecanisée, (Frankfurt, Suhrkamp Verlag, 1980), 717.

"Film, by virtue of its shock effects, is predisposed to this form of reception. In this respect, too, it proves to be the most important subject matter, at present, for the theory of perception which the Greeks called aesthesis, Benjamin, Kunstwerk, 466.

By its use of close-ups, by its accentuation of hidden details in familiar objects, and by its exploration of commonplace milieux through the ingenious guidance of the camera; on the other hand, it manages to assure us of a vast and unsuspected field of action [Spielraum], Benjamin, $L$, oeuvre d'art, 717. 
Benjamin, Walter. Das Kunstwerk im Zeitalter seiner technischen Reproduzierbarkei. Frankfurt, Suhrkamp Verlag, 1980.

Benjamin, Walter. L'oeuvre d'art à l'époque de sa reproduction mecanisée. Frankfurt, Suhrkamp Verlag, 1980 .

Goetz, Benoît - La dislocation. Architecture et Philosophie. Paris, Les éditions de la Passion, 2002.

G. W. F., Hegel, Cursos de Estética. Translated by Marco A. Werle/Oliver Tolle. São Paulo: EDUSP, 2000. 


\section{ESTETIKA ODRŽIVOSTI: ARHITEKTURA KAPSULE U GRADU I U PRIRODI Peter Šenk}

Arhitektura najmanjih mesta za stanovanje je u poslednje vreme izuzetno popularna tema. Kada su najmanja mesta za stanovanje kompaktna, dobro opremljena, povezana na mrežu, strukturno, funkcionalno i vizuelno prepoznata kao jedna stvar, privremena i pokretna ili prenosiva, mogu se označiti kao arhitektura kapsule. Budući da su po svojoj prirodi privremena, ova najmanja mesta za stanovanje, skloništa, redizajnirane kontejnerske jedinice, posebne tehnološke konstrukcije, paraziti i druge manifestacije koncepta kapsula obuhvataju logiku tehnoloških objekata s izrazitim arhitektonskim izrazom. To je, istovremeno, manifestacija pravila održivog dizajna, održive arhitekture i održivosti uopšte. U ovom kontekstu slučaj najmanjih mesta za stanovanje pokazuje svoju razliku u odnosu na druge održive arhitektonske pristupe i estetike. Podredjuje uopšteno održive pristupe sa izraženim značajem lokaliteta unutar globalnih sila, obično se oslanjajući na kontekst - lokaciju, lokalnu kulturu i karakteristike životne sredine itd. Estetski režim trenutnih, promenljivih, kontekstualnih i autonomnih arhitektonskih struktura se može posmatrati kao estetika drugosti, koja ih povezuje sa nasledjem egzistencijalnih eksperimenata modernog pokreta, novim brutalizmom, radikalnim eksperimentima 1960-ih i drugim avangardnim i neoavangardnim praksama dvadesetog veka, ali čvrsto postavljenim u kontekstu individualizovane, neodredjene, raspršene i dvosmislene savremenosti.

KLJUČNE REČI: ESTETIKA PROMENE, KAPSULE, NAJMANJA MESTA ZA STANOVANJE, MINIMALAN TRAG, DRUGOST, ESTETIKA ODRŽIVOSTI

\section{ESTETIKA I KULTUROLOŠKI ASPEKTI BAUHAUSA: \\ KA NOVOJ KONCEPCIJI}

\section{Christiane Wagner}

Ovaj članak pokriva nove mogućnosti Bauhaus pogleda na svet: stvaranje novih oblika za prikazivanje ljudskih ideala kroz fokus na estetiku i tehnologiju, u kombinaciji sa Nimajerovim (Niemeyer) uticajem na arhitekturu i dizajn. Novi stilovi i oblici nastali su kao izdanci Bauhausa, prenoseći vrednosti svake kulture kroz izgradnju kolektivne „slike“ sveta. Bauhaus današnjice izražava industriju kulture, dijalektički razmatrajući inovaciju i primenjenu umetnost kao put od modernog dizajna industrijske revolucije do „eko dizajna“. U tom smislu, Bauhaus je još uvek značajan po svojoj ulozi, povezujući umetnost, tehnologiju i industriju. Inovacija kao dinamično odredjivanje trenutka, prisutna u svim epohama, se shvata kao moćna sila za održavanje tradicije. Pored hronološkog zapisa o uticaju Bauhausa, razmatraju se i značajni Nimajerovi projekti. Na kraju su prikazane dve perspektive ,raskola“ izmedju arhitekture i tehnologije. Prva perspektiva se odnosi na ljudsku sposobnost stvaranja modela u arhitektonskoj praksi za usvajanje kao konfiguraciju prostora. Druga se odnosi na evoluciju tehnologija koje vode do toga da zamišljeno postaje stvarnost kroz vreme, kako je to opisao Hegel (1823).

KLJUČNE REČI: IZRADA PO MERI, TEHNOLOŠKI RAZVOJ, PROSTOR-VREME, NOVI OBLICI

\section{KLASIČNA ARHITEKTURA U OKVIRU KANTOVSKE ESTETIKE: IZMEĐU LIOTARA I RANSIJERA}

\section{Helen Tatla}

Potencijal koji je svojstven klasičnoj arhitekturi da predstavlja glavni arhitektonski izraz zapadne kulture budući da je grčka antika nastala zbog svog dualnog karaktera: iako izvire iz iskonskog jedinstva stvari izraženih mitom i religijom u arhaičnim vremenima, ona dobija svoj završni oblik u petom veku p. n. e., kao simbol demokratije i harmonične artikulacije sveta na osnovu filozofskog mišljenja. 
Postavljajući avangardnu umetnost u sferu kantovske uzvišenosti, Žan Fransoa Liotar (JeanFrancois Lyotard) se fokusira na nemogućnost apsolutnog odnosa razuma i percepcije ili između razmišljanja i slike, u savremenosti. On smatra da se u slučajevima kada se to dogodi radjaju politička čudovišta. On povezuje postmoderne izraze klasicizma u arhitekturi sa Frojdovim „Tumačenjem snova“" i kantovskom lepotom.

Pristup Žaka Ransijera (Jacques Ranciere) kantovstvu na osnovu estetskog razmatranja modernosti suprotan je onome koji je predložio Liotar. Umesto uzvišenog, Ransijer povezuje lepo s pukotinom izmedju razmišljanja i percepcije. U tom pogledu, fragmenti prošlosti mogu da podstaknu kreativni proces u sadašnjosti.

Cilj ovog istraživanja je da doprinese dijalogu o obnovljenom pristupu ulozi klasicizma u arhitekturi danas.

KLJUČNE REČI: KLASIČNA ARHITEKTURA, KANT, LIOTAR, MODERNOST, POLITIKA, POSTMODERNOST, RANSIJER

\section{FLUIDNO STANJE ARHITEKTURE}

\section{Bojana Jerković-Babović}

Ovaj rad se bavi promenama u kriterijumima arhitektonske estetike, transformacija statičnih u dinamične vrednosti podjednako figurativnih i nefigurativnih aspekata savremene arhitekture i njenog konteksta. Fluidno stanje arhitekture odnosi se na prepoznavanje konstantne promenljivosti koja se manifestuje u relacijama arhitekture i savremenom kultuloroškog konteksta globalizacije. Savremeni kontekst dinamizuje perceptivna iskustva svakodnevnice, uslove života i načine prostornih aproprijacija. U skladu sa tim, novi fenomeni umreženosti koji se manifestuju na informacionim, komunikacionim i prostornim nivoima transformišu grad i arhitekturu u konstantne procese tokova, kojima se njihovi elementi dematerijalizuju u nove fluidne, promenljive karakteristike. Vredosti arhitektonske estetike istovremeno se transformišu ka afirmaciji dogadjaja i efekata naspram statične formale celine, od objektivnih do intersubjektivnih estetskih prostornih iskustava.

Ovaj rad se bazira na hipotezi da savremenu arhitekturu karakteriše gubitak singularnosti objekta u odnosu sa uslovima konteksta i asimilacija karaktera pojedinačnih elemenata u fluidni karakter celine. Na taj način, arhitektonske projektantske principe karakteriše disperzija disciplinarnih granica i granica unutrašnjosti i spoljašnjosti, hibridnost i gubitak tipoloških definicija. Ovaj rad prikazuje kako dematerijalizacija arhitektonskih vrednosti transformiše savremeni arhitektonski prostor u kompleksan dinamički sistem infrastrukture, tokova, događaja i efekata.

KLJUČNE REČI: ARHITEKTONSKA ESTETIKA, ARHITEKTONSKO PROJEKTOVANJE, ESTETSKO ISKUSTVO, DINAMIČKE VREDNOSTI, FLUIDNOST, GLOBALIZACIJA

\section{KINEMATOGRAFIJA I ARHITEKTURA: MODERNA PERCEPCIJA Sônia Campaner Miguel Ferrari}

Esej Valtera Benjamina (Walter Benjamin) o bioskopu objašnjava njegove prognostičke vrednosti. Dok je pisao ovaj članak, njegova kritika kapitalističkog načina produkcije pokazala je pravac u kojem kapitalizam napreduje: ka sve većoj eksploataciji proletarijata, ali i ka svom vlastitom padu. Nas zanimaju ove prognoze koje potvrdjuju transformaciju umetnosti i njene funkcije, a koja našu pažnju usmeravaju na gubitak transcedencije i opadanja aure umetničkog dela. One u isto vreme pokazuju mogućnosti kojima se potvrđuje kontinuitet umetnosti koja ima drugačiju ulogu i dislokacija aure. Oblik umetnosti koji je pogodan za ovakvo razmišljanje je kinematografija i paralela koju je filozof povukao izmedju kinematografije i arhitekture. Namera nam je da se osvrnemo na ovu paralelu i urbane intervencije kao umetničke oblike estetske modernosti: to 
jest, kao proizvode ove modernosti koji istovremeno ukazuju na način koji nam je dat i shvaćen. Takodje ćemo se osvrnuti i na indikacije bioskopa i pozorišta kao načina da se prevazidju telesne odrednice koje nam se nameću.

KLJUČNE REČI: ARHITEKTURA, BIOSKOP (KINEMATOGRAFIJA), MODERNA UMETNOST, MODERNA PERCEPCIJA, URBANIZAM

\section{AUTORSTVO I JEZIK U KNJIGAMA SAVREMENIH ARHITEKATA}

\section{Deniz Balık Lökçe}

Ovaj rad se bavi ispitivanjem teorijskih, grafičkih i materijalnih dimenzija savremene kulture štampe u arhitekturi sa fokusom na po jedno delo iz različitih evropskih praksi. Knjiga savremenog arhitekte posmatra se kao spekulativni i diskurzivni predmet dizajna. Mišel Fuko (Michel Foucault), posebno u svojim delima, Šta je autor? (1969) i Arheologija znanja (1972), kritikuje to da se prilikom izrade opusa jednog autora alternativni i neklasifikovani žanrovi izostavljaju iz domena, a tekstovi koji se vezuju za jedno ime pripadaju sistemu homogenosti, veze i recipročnog objašnjenja. Ipak, knjiga savremenog arhitekte proširuje granice žanrova tako što je sačinjena od nekonvencionalnih materijala, poput muzičkih nota, umetničkih fotografija, slika, tehničkih i naučnih dijagrama, zvaničnih izveštaja, gradjevinskih propisa, novinskih članaka i reklama, a takođe i od kombinacije tekstova i fotografija saradnika, partnera, klijenata i korisnika, a ne samo kao produkt jednog autora. Ovaj rad se bavi tumačenjem korišcenja različitih oblika grafičke naracije i spajanja nove terminologije i žargona kao doprinosa moći jezika i diskurzivnoj formaciji.

KLJUČNE REČI: ARHITEKTONSKI MEDIJI, ARHITEKTONSKA MONOGRAFIJA, KNJIGA, FUKO, ŽANR, KULTURA ŠTAMPE, AUTOR, TEKST

\section{ARHITEKTURA KAO TEKSTUALNI FENOMEN: APROPRIJACIUSKE ARHITEKTONSKE PRAKSE ALEKSANDRA BRODSKOG Boško Drobnjak}

Tekst analizira arhitekturu nastalu aproprijacijom postojećih materijala fokusirajući se na strategije intertekstualnosti. Rad zastupa tezu da značenje arhitektonskog objekta ne proizlazi iz njega samog ili njegovih poetskih koncepata, već iz njegovih odnosa sa drugim arhitektonskim objektima, drugim umetničkim delima kao tekstovima, kulturalnim tekstovima i svakodnevnim životnim praksama. Cilj rada jeste da se pokažu različiti teorijski problemi teorije arhitekture i umetnosti koji kao mreža uodnošenih tekstova kulture okružuju arhitektonsku produkciju Aleksandra Brodskog (Alexander Brodsky). Za metod rada je karakteristično operisanje sa različitim i raznorodnim teorijskim konceptima, uzimajući odabrane studije slučaja (Votka paviljon i Rotunda) arhitekture Brodskog u okviru koje je rad koncipiran kao interdisciplinarna studija.

KLJUČNE REČI: ALEKSANDAR BRODSKI, APROPRIJACIJA, SVET UMETNOSTI, EKSPERIMENTALNA ARHITEKTURA, READY-MADE, TEKST

\section{PITER AJZENMAN I MOGUĆNOST ESTETSKOG FORMALIZMA \\ Amund M. Rolfsen}

Formalna razmatranja predstavljaju srž aspekta rada Piter Ajzenmana (Peter Eisenman). Može se tvrditi da su ona jedina dosledna tema njegovog rada, i zasnivaju se na konceptu da je arhitektura posredovanje izmedju otelovljenog unutrašnjeg sveta ljudskih bića i spoljnog fizičkog sveta koji naseljavamo. Ajzenman tako daje „konceptualnu“, a ne percepcijsku osnovu, pri čemu su univerzalni formalni odnosi važniji od čulnih aspekata. Na taj način arhitektura ostaje kao 